\title{
Ett år i New England Journal of Medicine
}

Tidsskrift for Den norske legeforening har som medlem i Committee on Publication Ethics (COPE) og International Committee of Medical Journal Editors (ICMJE, den såkalte Vancouver-gruppen), tett kontakt med de store internasjonale medisinskvitenskapelige tidsskriftene (1). Som medisinsk redaktør i Tidsskriftet fikk undertegnede anledning til å arbeide som «editorial fellow» i New England Journal of Medicine (NEJM). Der har de i ca. fire år hatt en ordning med årsengasjement for en editorial fellow, som oftest en yngre lege med interesse for medisinsk forskning og publisering. NEJM er verdens høyest rangerte generelle medisinske tidsskrift. Det utgis 52 ganger i året og leses over hele verden. Det ble grunnlagt i 1812 som New England Journal of Medicine and Surgery, og har siden 1928 vært utgitt under sitt nåværende navn. Eieren og utgiveren er legeforeningen i Massachusetts, Massachusetts Medical Society. Redaksjonen holder til i Boston, i øverste etasje av Countway Library, det medisinske biblioteket på Harvard Medical School.

Staben er på om lag 70 medarbeidere, det er mange sammenliknet med andre medisinske tidsskrifter. Sjefredaktør Jeffrey M. Drazen, hans to stedfortredende redaktører og sju medisinske redaktører (deputy editors) utgjør kjernen i det redaksjonelle teamet. De medisinske redaktørene jobber for redaksjonen fire dager i uken, mens en dag skal vies til klinisk arbeid eller forskningsarbeid for ikke å miste kontakten med disse miljøene. I tillegg finnes det 11 fagredaktører (associate editors). Disse er eksperter på sitt fagfelt, ofte professorer ved Harvard eller ved et av de andre tre medisinske fakultetene i Boston, ansatt i deltidsstillinger i NEJM. Alle redaktørene møtes to ganger i uken for å diskutere manuskripter. Disse møtene er preget av grundige og dyptgående diskusjoner om innsendte manus, og også om prinsipielle avgjørelser, samt medisin, vitenskap og helsepolitikk generelt. Møtene har ikke noe definert sluttidspunkt; man diskuterer til alle aktuelle manuskripter er behandlet. Dette er noe uvanlig for våre norske forhold, med andre forpliktelser etter vanlig arbeidstid.

NEJM har egne avdelinger for språklig gjennomgang av manuskripter og for medisinske tegnere som lager illustrasjoner til tidsskriftets artikler og nettsider. Det satses stort på nettet som publiseringsmedium (2), og det arbeides kontinuerlig med nye digitale løsninger for medisinsk publisering. Et av prosjektene i den senere tid har vært å lage en egen nettside om svineinfluensa, med ny originalforskning, ledere og informasjon til helsepersonell og publikum generelt. Dette såkalte «H1N1 influenza center» (3) var i drift etter kun ca. tre ukers planlegging.

Hvert manuskript innsendt til redaksjonen blir sett på av sjefredaktøren, som regel samme dag som det blir sendt inn. Noen refuseres direkte, alle andre tildeles et redaktørpar bestående av en fagredaktør og en medisinsk redaktør. Om lag $45 \%$ av de innsendte manuskriptene sendes av dette paret ut til ekstern fagvurdering, resten refuseres på dette stadiet. De manusene som får positive fagvurderinger og/ eller blir positivt vurdert av det ansvarlige redaktørparet, presenteres på et redaksjonsmøte. Den ansvarlige fagredaktøren legger frem manuset, viser tabeller og figurer, sammenfatter fagvurderingene og gir et forslag til konklusjon, som kan være videre arbeid med manuskriptet eller refusjon. Fagredaktør må ofte svare på detaljerte spørsmål om innhold, metode, fremstilling og litteratur. Diskusjonene kan være lange og noen ganger livlige, med mange, til dels svært ulike meninger om enkeltmanus. De manuskriptene som overlever møtet (ca. $10 \%$ av alle innsendte), vurderes av en av fire statistikere, som er deltidsansatt i tidsskriftet. Manusene tilbakeføres så til den ansvarlige medisinske redaktør for videre bearbeiding. Denne delen omfatter ofte mange runder med forfatterne på e-post og telefon, med presiseringer, omfattende omskrivninger og nye analyser. Det er ikke sjelden at artikkelen som kommer på trykk, inneholder en annen konklusjon enn den i den først innsendte manusversjonen. En del manuskripter blir refusert også på dette stadiet, fordi de allikevel ikke holder mål. Det kan være problemer med tillatelser, studieregistrering, etikk, statistikk eller andre forhold. Om lag $6 \%$ av alle innsendte originalartikler blir til slutt publisert.

Som editorial fellow har jeg deltatt på møter og i redaksjonelt arbeid med manuskripter innen mitt fagområde (gastroenterologi) og hatt ansvar for spalten «Images in Clinial Medicine», der det publiseres to korte pasientkasuistikker med fotografier eller videoer hver uke. Jeg har også gjennomført et forskningsprosjekt der jeg har sammenliknet refuserte originalmanuskripter som var innsendt til NEJM for publisering i årene 1995 og 2003 med henblikk på senere publisering $\mathrm{i}$ andre medisinske tidsskrifter.

Mylderet av ulike typer forskning og pasientbehandling er enormt, og mulighetene for studier, seminarer og foredrag av begavede og dedikerte klinikere og forskere er utallige på Harvard campus. NEJM er en sentral del av dette. Miljøet er entusiastisk og det hersker en utbredt «ja-holdning». Er man flink og ønsker å gjøre en god jobb, får man støtte, veiledning og om nødvendig de økonomiske rammene som skal til for å være god. Det medisinske miljøet i Boston har rykte på seg for å være snobbete, og miljøet har et selverklært krav om å være best i verden. Men det som dominerer, er en inkluderende og positiv innstilling som gjør at det er inspirerende å beskjeftige seg med medisin i Boston. Etter ett år er jeg imponert over kunnskapsnivået og over det arbeidet som legges ned i manuskriptene som vurderes. Faglig kvalitet er det primære kriteriet for godkjenning. Det er rom for mange meninger, og alle manuskripter diskuteres nøye. Det er det betryggende å vite, selv om man ikke alltid vil være enig når man får refusert et manus.

Det har vært interessant å se at arbeidsprosessene og organiseringen av det redaksjonelle arbeidet i NEJM og i Tidsskriftet i stor grad likner hverandre. Selve manuskriptarbeidet er også svært likt, men skiller seg klart fra bearbeiding av manus i mange spesialtidsskrifter, som ofte ikke er på det samme detaljnivået. Det er viktig for forfatterne og leserne å være klar over at den virkelig tunge og krevende jobben med manus oftest først begynner etter første revisjon, både i NEJM og i Tidsskriftet.

\section{Michael Bretthauer}

mbretthauer@nejm.org

Michael Bretthauer er medisinsk redaktør i Tidsskriftet og var editorial fellow i New England Journal of Medicine i perioden august 2008 til juli 2009.

\section{Litteratur}

1. International Committee of Medical Journal Editors. www.icmje.org (17.9.2009)

2. The New England Journal of Medicine. http://content.nejm.org [17.9.2009].

3. The New England Journal of Medicine. H1N1 influenza center. http://h1n1. nejm.org (25.8.2009). 